UDK: 821.511.141.09-1 Леши 3.

821.511.141.09-1 Хорват И. О.

821.511.141.09-1 Олти П.

DOI: https://doi.org/10.18485/25bghun.2021.ch18

\title{
CSEHY ZOLTÁN
}

Pozsonyi Comenius Egyetem, Bölcsészettudományi Kar, Magyar Nyelv és Irodalom Tanszék

\section{A (szöveg)test mint csatamező és játszótér}

\section{Összefoglaló}

A tanulmány három fiatal magyar költő (Lesi Zoltán, Horváth Imre Olivér és Olty Péter) új verskötetével foglalkozik a heteronormatív elvárásrendszer és a queer tematika közti poétikai és retorikai feszültség viszonyrendszerére fókuszálva. A szerző feltérképezi a hagyomány queerelésére vonatkozó stratégiákat, és e módszer segítségével bemutatja az énformálás performatív aktusait, a klasszikus szöveghagyományba való intertextuális beavatkozásokat, az én, a nem, a norma fragmentálódásának szimptómáit. Lesi Zoltán az interszexualitás és a sport hatalmi stratégiáinak (mint a politikai és ideológia agresszió metaforájának) viszonyát dolgozza fel, Horváth Imre Olivér egy új camp mitológiát teremt, Olty Péter pedig a klasszikus mitológiai álca és a számítógépes játékok stratégiáit felhasználva oldja fel a heteronormativitás szabályrendszerét.

Kulcsszavak: queer, kortárs magyar költészet, interszexualitás, heteronormativitás.

Az előadás három fiatal kortárs költő verskötetének szövegeit, hipernarratíváit vizsgálja meg a heteronormatív rezsimmel való szembeszegülés szempontjából. A szerző a hagyomány „queerelésének” költői technikáit és stratégiáit térképezi fel, miközben a labilis énkonstrukciók olyan hálózata bontakozik ki, mely alapvetően kérdőjelez meg evidensnek vélt kategóriákat, és a tradíció felnyitása révén új esztétikai játékteret is teremt. Lesi Zoltán Magasugrás című kötete (2019) pl. az interszexualitás és a sport hatalmi-politikai agresszióval átitatott diskurzusát hozza játékba. Horváth Imre Olivér egy a viktoriánus angol 
diskurzushoz, illetve camp mitológiához kötődő virtuális költői plasztikai sebészet „homunculusait” teremti meg nem szimpátia (2016) címü könyvében, Olty Péter pedig a heteró közeg diskurzusnarratíváját fordítja meg többek közt a videójátékok vagy az akként felfogott mitológia irányából Heteró közegben (2019) címmel publikált munkájában.

Christopher Reed müvészet és homoszexualitás viszonyát vizsgálva hangsúlyos szerepet szán a normalitás/deviancia ütközőterének. E tér konfliktusai, müvészeti eseményei mind külső, mind belső szempontból megjeleníthetőek, jelentős módon bukkannak fel hol provokatívan, hol metaforizált jelekként vagy maszkokként az erotizált tárgyi vagy retorikai környezetben, és jelentős tárgyát képezik a szubkulturális vagy a szükségszerúen átpolitizált kisebbségi művészetnek is (Reed 2011: 6-9). Nincs ez máshogy az irodalomban se: annyit mindenesetre érdemes finomítani a rendszeren, hogy nem pusztán ütközőtérről, hanem olykor provokatív játszótérről is szó van. Judit Butler hívta fel többek között a figyelmet arra, hogy a heteronormativitás vagy a heteroszexuális mátrix természetességét a nemi identitások performativitásának rituális ismétlődései teremtik meg (Butler 2006: 91-96): ez a séma pedig csak úgy mozdítható ki, ha a zavart, a túlzást, a színjátszást, a teátralitást, a disszonanciát is belekomponáljuk az ismétlésekbe, azaz, ha tudatosan „rosszul” ismételjük meg a performatív rítust. A szexualitásnak nincs eredetije és másolata: a társadalmi nemi normák ismétlései épp erre döbbenthetnek rá (Jagose 2003: 83-89), miközben a normaismétlésekben - kényszer vagy önmegvalósítás hatására - így is, úgy is szubjektum konstruálódik.

Lesi Zoltán kötetében a normalitás/deviancia tere kettős tér: az elbeszélt anyag, a történeti interszexualitás, a nemek között ragadt egyén konfliktusa a maga korának heteronormatív eljárásrendszerével a normalitás/deviancia ütközőterét a maga legradikálisabb hadiállapotában mutatja be, ugyanakkor a költői elbeszélés jelene már inkább retorikai játszótérként kezeli ugyanazt, hiszen a retorikai performativitás keretein belül konstruál sajátos szubjektumokat a társadalmi nemi konstrukciók hibás „előadásai”, performatív gesztusai során. A müfaj követi ezt a 
kettősséget: a fülszövegen a traumaelbeszélés mellett a szórakoztatást megcélzó „genderkrimi” terminus is felbukkan. Lesi Zoltán Magasugrás címü kötete ún. konceptkötet. Erre a verskötettípusra jellemzö, hogy a hipernarratíva, mely a versszövegek fölé nő, egyszerre számolja fel a hagyományos verskötet tabuláris olvasati lehetőségének szabadságát, és egyszerre terjeszti ki legitimáló erejét az önmagukban esetleg gyengébb, dramaturgiai okokból elhelyezett szövegekre is. A kötet fő témáit az interszexualitás és a sport ürügyén kibomló hatalmi játszmák lelepleződései alkotják, egy többszereplős, hol nyílt, hol sugalmazásos pszeudodokumentarista (vallomásokat, kihallgatási jegyzőkönyveket, kávéházi anekdotázásokat idéző) traumaelbeszélés-sorozat foszlányai képezik (Csehy 2019: 19). A borostás, Európa-bajnok magasugrónő, Dora Ratjen 1938-ban lebukik egy zsemlevásárlás alkalmával, $\mathrm{s}$ a hatóságok férfinak minősítik (Fakabát, Lesi 2019: 58). Miközben „női ruhában ő igenis / a Harmadik Birodalom érdekeit szolgálja" (Lesi 2019: 58), végül megfosztják érmeitől és korábbi nemétől is. És épp a magyar Csák Ibolya taszítja le a nemileg determinált dobogóról. A kultúrtörténetet és a megalázások történetét azonban nem lehet kisminkelni: a borosta mindig ki fog ütközni. A manipulációk hatalmi rendjét ügyesen dokumentáló verskötet a náci esztétika és antietika játékterében éri el a legnagyobb hatást, többek közt a zsidó Gretel Bergmann tragikusan beszivárgó történetével, aki tizennégy éves kora óta 34 német érmet nyert, majd Angliába szökött. A nácik a családjával zsarolták a visszatérés érdekében, ám mégsem küzdhetett az olimpián, helyette az interszexuális Dora Ratjent küldték. Az elvakult ideológia kitalálja az embert, a nemét, a testét is megalkotja, s úgy használja, ahogy a helyzet kívánja: annyiszor adatja elő a rituális ismétlésekbe merülő szubjektummal a kívánt „nemet”, ahányszor csak akarja. „Szerinted fiú vagyok vagy lány?” - kérdezi az akkor már Heinz Ratjen egy fiktív levélben Gretel Bergmanntól (Lesi 2019: 64). „Éreztem, / nem lány vagy fiú vagyok, / hanem a kettő között" - konstatálja végül, majd a hatalommal szemben, mintegy anticipálva lehetséges sorsát felteszi a kérdést: „Megválaszthatom / a kínzóim nemét?" Dora maga végül a férfilétet választja, merő hatalmi-társadalmi 
opportunizmusból. A tökéletes német nö II. címü szöveg Dora Ratjen átváltozását ugyan így jellemzi: „a fiús lányból / lányos fiú lett” (Lesi 2019: 79), vagyis a sztereotip férfiasság vélt helyén az effemináltság queer diskurzusa képződik meg. Sőt: Lesi tovább megy, hasonlatokban Ratjen énjére más éneket is rákopíroz, pl.: „olyan szomorú, mint Herculine Barbin, vagy Garfield karácsonykor” (A kamera leáll, Lesi 2019: 89).

A biológia a kötetben egyszerre börtön és kreatív játszóház. Lesi kötete a kategorizálás fasizmusát, a sztereotípiák aknamunkáját a magasugrás és az interszexualitás narratíváján keresztül mutatja be; dokumentumokat, költői (ál)dokumentumokat vonultat fel, s így a kötet nyelvezete is jobbára alulretorizált, szikár, tényközlő marad. A feszülő izmok pragmatizmusa. Mezei Gábor recenziójában felhívja a figyelmet a „bedobozolás” technikájára, mely Joseph Cornellhez kötődve jelenik meg a szövegben és ,a talált tárgy esztétikájára és Cornell hordozható múzeumaira" utal (Mezei 2019: 19). Ehhez tehetjük hozzá, hogy az emlékdobozolás mellett a szexualitás bedobozolásáról is szó van, a closetról, melyet „szekrényezettségnek” lehetne fordítani, s mely a nemi identitás elrejtéséröl szól, a coming out ellenpontját képezi. A versek sokszor a normatívnak tételezett identitáskonstrukciók kényszerkiugratásáról szólnak. Az Inaktív X. című szövegben (Lesi 2019: 59) a megszakított interjú és a tudományos, genetikai szövegdiskurzus (Barr-teszt) vegyül, aminek elsődleges célja nem is a költői regiszterkeverés erejének használata, hanem az orvosi diskurzus technikájának leleplezése, ahogy hatalmi pozícióból megteremti a deviáns alakját és démonizálja azt. A Barr-teszt csődjét a test maga mondja ki, erre példa Ewa Janina Kłobukowska, lengyel futónő esete, aki „hermafroditaként / nyert női versenyen", s akit a Barr-teszt alapján férfinak nyilvánítottak. Kłobukowska viszont mintegy válaszként az abszurd kromoszómatesztre, egy év múlva gyereket szült. A kiváló csehszlovák futó, Zdeněk Koubek példája, aki Zdena Koubková néven született, a nem-adás pragmatikus mechanizmusait is a kötet diskurzusába vonja: „Young azt mondta, van péniszem, / csak ki kell 
szabadítani” (Lesi 2019: 67). A nőben rejlő férfit sikerült kibontani, a nős Koubek 73 évesen halt meg.

Lesi könyvében az orvosi, az áltudományos és a gendertörténeti diskurzushoz társul a zoológiai szaknyelv regisztere is. Kiemelt szerepet kap a homárok interszexualitása: a hímek jelentős része ugyanis női ivarmirigyekkel is rendelkezik. Az állatvilágbeli analógiák, legyenek bármilyen bizarrok is, a természetesség érvrendszerének konstitutív elemei közé tartoznak.

A kötetet Ricardo Portilho képzőmüvész tervezte, aki számos assemblage-zsal van jelen: minden identitás, narratíva, minden verskötet assemblage, sokféle elemből építkező, bedobozolt, önmagunkban talált és hozzánk kötött tárgyak konstellációja.

Horváth Imre Olivér kötetében a bőr-textúra, a felszín horzsolása, megsebzése, a varrat-retorika és a megkonstruált, összevarrott, mütött vagy épp összefércelt test, bábu vagy karakter játszik fontos szerepet. A hám alól új bőr születhet: az új bőrben új aktuális identitás konstituálódhat (Horváth 2016: 36). „Horváth verseiben szinte mindig világossá válik, ki is a beszélő, azonban a megnyilatkozó identitása versről versre váltakozik" - írja Konkoly Dániel (Konkoly 2017: 106). Ez a narratív „világossággal” kombinált változékonyság a színre vitt nemi konstrukciókkal együtt adja a kötet dinamikáját. Ennek a kettős textúrának a nem is konstitutív része: a nyitó vers (Az anglász) nem pusztán Debrecenbe helyezi át, a „második legnagyobb magyar várost”, Londont, nem pusztán a környezetre operálja rá a brit felszínt, hanem az emlékezet mütéteinek részévé teszi azt az elképzelt múltat is, mely „Viktorból Viktóriába operál” (Horváth 2016: 7). A szerep és a monológ a testi faktort teszi a legelbizonytalanítottabbá: a test ,az információ útjában áll” (Horváth 2016: 12), az állásmeghallgatás színjátékában megképzett szfinxszerű „,businessman” (,arrogáns, / magas, ép orr, Versace, Rolex, mellszőr a résben" tökéletes ellentéte a bölcsésznek, és a szexuális hierarchia is azonnal evidensen összefonódik a szereppel, a homoszocialitás köznapi pornográfiájával: „ő kommunikálni tud, én csak közölni, felszopni”, monologizál a vers narrátora (Horváth 2016: 13). A test folyamatosan kontrasztba 
kerül a társadalmi nem rituális újrajátszásaival: képtelen elviselni, amit rámér a kényszerü performativitás. A test lesz érdekes módon a szabadság terepe, a lázadás zsigeri anyaga. A vér, a hús, a hám, a bőr lázadásának versei ezek.

A kötet három ciklusa három szerző nevét viseli: az első az amerikai Henry Jamesét, a másik az ír Bram Stokerét, a Drakula szerzőjéét, a harmadik az angol Charlotte Brontë nevét kapta. A játékba vont potenciális szöveguniverzumok viszont át-átszivárognak a ciklushatárokon: a Vérivás címü vers pl. a James-ciklus zárlata lesz, az A csavar fordul egyet kísértetvilágát is megidéző Héraklész pedig a Brontë-sorozatban állapodik meg.

Horváth Imre Olivér a könyvét „transzvesztita” könyvnek nevezte egy bemutatón (Bihary 2016), ami mind a szerepjátszás és az identitásmegsokszorozódások alkalmi változékonyságát, mind a szerzői alapállás képlékenységét mutatja. Horváth Imre Olivér nyelvének travesztiáira is folytonosan figyelni kell: bizonyos szubkulturális jelentéstartalmak (ilyen pl. a meleg, a köcsög vagy a nem szó maga is - ahogy Lesinél a homár) a folyamatos szerepjáték rítusait leplezik le. Ezek a stigmatizáló jelzések mutatják a maszkjelleget.

A Legénylakásban ámuldozó szigetelőmunkás tudja, „hogyan kell élni, / nemzeni és szépen halni meg”, de azt is, hogy hogyan kell benn tartani a meleget. $\mathrm{Az}$ értelemcsuszamlások játékos apróságai Horváth verseinek fontos elemei (Horváth 2016: 16), akárcsak az átmeneti létállapotok ember és vámpír-, szirénvagy succubuslét között. A jelentés ereje kettős, a nem tagadószói és fónévi értelme időnként dominánssá válik. A Vérivás című vers hét magyarja között a pincér, a masszőr, a menekültpárti tévéfüggő, az öltönyös mellett megjelent egy apa, illetve egy a „nőies, ideges, / hisztérikus, fecsegő, ferde kort” kritizáló alak is, aki valamennyi negatív tulajdonságot az effemináltságtól a perverznek tartott magatartásig a normativitással szembeállítva határozott meg. A hetedik magyar „,egy köcsög volt, aranyozott szájú, / ittak belőle mindahányan”. A hetedikben attól függetlenül találkozik a hét karakter, hogy az illetők milyen módon vélekednek a normalitás/deviancia ütközőtérről: a szavaknak a gyakorlatban használatuk és nem jelentésük van (Horváth 2016: 24-25). 
A férfiassággal való szembenézés, a maszkulin egyértelműség, a férfitest nézhetetlensége, tárgyiasíthatatlanságának tabuja (a férfi, aki néz, a nő, akit néznek alapsémája) jelenik meg a Gentlemen c. versben, mely így kezdődik: „Egy férfivécében nincsen tükör. De nézzük, / a piszoár fölötti billentyü krómján hogyan / verődnek vissza a tisztelt farkak” (Horváth 2016: 32). A „tükröt összetörné bármelyik vadállat" fordulat világosan definiálja a maszkulin sztereotípiát, melyhez az egyén idomulni igyekszik. A szöveg Pilinszky János Napló címủ versére (Pilinszky 1992: 127) is reflektálni látszik, mely egy öregúrral közös vizelést ír le, egy könnyen szubkulturális ismerkedési aktusként is érzékelhető helyzetet. Ebben a versben a férfivécében van tükör, ám az csak metaforikusan törik el: benne ,mintha egy bárány / tört-zúzott volna, / ott valami nagy szelídség / azt mondta: megítéllek téged!” (Csehy 2014: 439). Horváth szövege kontrasztív módon játssza újra Pilinszky-versét, miközben leleplezi annak homoszociális erotikáját.

A Porphyria c. vers anyafigurájára a tükör bezzeg visszakacsint, igaz, a tükörkép megfiatalítja („mintha csak bakfis lányka volnék”), ám e boldogság alapszabálya, hogy nem szól bele „a férfiak dolgába” (Horváth 2016: 51-52). A tükör a női térfél kiemelt tárgya lesz.

A maszkulin rettegés az elfojtáson alapszik: Horváth a Dorian Gray-paradigma varázstalanítása után jut el Az anglász 3. címü versben a heteronormatív edukáció pedagógiájához, hogy leleplezze azt: „,valójában nem a francia dekadensek leprás / irodalmától félünk, sem az európai népességszám / drasztikus csökkenésétől, hanem attól, hogy - mert a testnek protézise a gyermek - meghalunk, mert / egyszer istenesen seggbe fognak kúrni” (Horváth 2016: 61).

A Héraklész-monológ (Horváth 2016: 53) a gyerekkori rettegés és az onánia hüdrájával megküzdő ént hozza elő: „,már csak a vért / és az ondót ismerem, mint egy igazi hérosz”, konstatálja az elbeszélő saját önazonosságának betetőződését. Ken baba tökéletes testével Medusza karakterének abszurd szépsége kerül szembe (Horváth 2016: 56). 
A tünékeny identitások genezise egy kislány monológjában realizálódik a leghatározottabban: „Szabika azt mondta, / hogy ferde hajlamaim vannak. A fiúk / annyira nem utáltak, velük játszottam. (...) Nem lány voltam, / hanem szar. Magamévá tettem a földet” (Horváth 2016: 38). A tudományos-normatív diskurzus beszivárgása a szövegbe a test- és létkonstruálás imperatívusza lesz, s ahogy Lesinél a kromoszómateszt, itt a Szondi-teszt egzaktsága kerül elö: „megkérdeztem a cigány bácsit, hogy fürdik-e / velem, azt mondta, hogy ő nagyon forró vízben / fürdik, megértően bólogattam, hiszen én sem / szerettem nagyon forró vízben fürdeni, / homoerotikus tendencia, mondta a doktor, / anyu azt mondta, hogy a seggem lyukát is meg / kell mosni, homoerotikus tendencia, mondta / a doktor, azóta szeretem a forróvizet, a zsíros / kenyeret, de a Szonditesztet nem, a hintát / sem, se a fiút, aki elkérte a kinderfiguráimat" (Horváth 2016: 43-44).

A Fiúszoprán címü versben a here testi pozíciója bizonytalanodik el a sztereotípiák függvényében (Horváth 2016: 49). A nem kilép a normatív keretek közül, s önmagán túli univerzumot teremt, köztességet és önállóságot hoz létre, akárcsak Olty Péter Erbarme dich címü opuszában, mely a sérülékenységet mint teremtő érzéki percepciót határozza meg (Olty 2019: 44).

Olty az orvosi diskurzus klasszikus kifejezéseit nyelvi analízis alá veti, s a homoszexuális, illetve heteroszexuális szavakat jelentésvesztett terminusokként értelmezi, melyek csak a nyelv müködését dokumentálják mindennemủ konkrét tartalom nélkül: a vágy ugyanis nem az azonosra irányul, hiszen az a másik felszámolásához vagy az én megkettőzéséhez vezetne el. A test nem vehető birtokba szavakkal, mert a test nyelve fellázad ellene. A Levélrészlet I. címü versben (Olty 2019: 25) a szexualitás kiiktatására is sor kerül, mivel az alany a szeretett nő iránt nem érez szexuális vágyat, ám a kapcsolat a másik vélt vagy feltételezett hiányának fantazmagóriájába pusztul bele. A szöveg formailag heteró viszonyt hoz létre, de lényegében testek nélkül, miközben a férfitest lázad a női ellen, a női pedig aszexuálissá csömörlik, a szexus a hiány helyét jelöli ki. Az Amfórarajz címü vers (Olty 2019: 35) egy antik tárgy díszítményeinek leírása 
alapján jut el addig a felismerésig, hogy nincs homoiosz, legfeljebb az egy sokszorosítása létezik, a mechanikus mintázat sokszorosítása viszont csak külső, járulékos körülmény, a lényeg nem lehet az azonosság. A homoszexuális kapcsolat nem ikerítés, hanem szintén heterogén elemek viszonya: a kötetcím Heteró közegben - tehát valójában a különbözöségeket hangsúlyozó „homoszexuális” viszonyokról szól. Olty azt a terminust lakja be, melyet tárgya ellenében találtak fel. A különbség, az elkülönülés, a heteró közeg túlhangsúlyozása, queerelése jelenik meg a Döntő kür címü szövegben is (Olty 2019: 23), mely szerint egy megkoreografálhatatlan haláltánc vagy revü résztvevői vagyunk.

A mitológia vagy a mitológiai sémarendszer mint pszichogramma-modell valóságosabb, mint az orvosi, jogi, társadalmi diskurzus normativitása és taxonómiája, hiszen, ahogy pl. az Alvilág címü (Olty 2019: 31) versböl is kiderül, mely egy meleg szauna terének leírása, a test gesztusnyelve önkéntelenül, terminológia nélkül is tökéletesen müködik. A testretorika spontaneitását elnyomja az állandó performatív készenlét, a szerep és a homlokzatépítés, holott a test - és itt belép a képbe Olty speciális és bizarr darwinizmusa - képes speciális érzékszerveket kifejleszteni, melyek önálló „fajt” hoznak létre. E faj egyedei (lásd pl. a Delfin címü verset, Olty 2019: 32), képesek lehetnek a másik megtalálására kifejlesztett szenzitivitást a percepciós készségek alapszervévé alakítani. Ebbe a konstrukcióba robban bele Hume, aki felteszi a kérdést, hogy az oksági kapcsolat valóban mélyebb-e annál a felismerésnél, hogy bizonyos dolgok gyakrabban szerepelnek egymás mellett vagy kerülnek egymás mellé, mint mások. Olty a Biliárdgolyók címü szövegben próbálja meg a kérdést újraszituálni, ironikusan játékba vonni Pilinszky János B. I. kisasszony címü versének (Pilinszky 1992: 148) rejtélyes golyó-motívumát („,De két golyó, mondjuk, hogy összekoccan. / Az is mi? Nincsen folytatása."), mely az érintkezés, az ütközés emlékének eltüntetését a „fedő bün” sejtelmes motívumával kapcsolja össze. Olty a biliárdgolyók egymásnak ütközését példázatként használja a hume-i szimpátiafogalommal rokonítható felfogáshoz (Horkay Hörcher 2012: 53), 
miközben egy gyerekkori szexuális vágy leírásába helyezve semmisíti meg a golyó motívum filozofikumát (,hártyaszerü bokszergatyája volt. / Golyói mint a szökdelő veréb.” Olty 2019: 33), és architextuálisan vulgarizálja Pilinszky szövegét, aki a versben „meleg alsót” kér. A queer performativitást ilyen harsányan felmutató játéktér a rosszul megismételt rítusok textuális játékaiba feledkező butleri elv színpadaival rokonítható. A rosszul eljátszott Pilinszky-vers (mint Horváthnál, itt is) leleplező erejü. Az oda-vissza mozgó érzelmek, a bölcseleti és a vulgáris érzetek egymás tükreiben visszaverődő energiái biztosítják a szövegek játékát. A kötetborítón szereplő Mars bolygó a férfiasság jelképe (lásd a Pantheon-erózió c. verset, Olty 2019: 41), de a „marslakó” lét jelképe is: ez a „vasoxidisten-szimulákrum” a férfiasság kozmológiáját mondja el a jelképiség szintjén, miközben a tudományos nyelvezet ki-kisiklatásával parodizálja az antik Mars-isten tiszteletére írt homéroszi Árész-himnuszt. Mars teste a bolygó webhelyekre feltöltött „,porszemekig lekopott valósága” lesz. Olty kötete utolsó ciklusában bevezeti a metamorfizálás fogalmát, mely a permanens átváltozás, a permanens „heteró közeg” alapállapotának energiaáramlását jelenti, s egyben a szövegek hagyományáradásának dinamikáját is modellálja. A kapcsolati dinamika és az érzékelés nyelvét a másság átváltozásait katalizáló érzelmek teremtik meg: az ősváltozat, a homoiosz nem érhető el, a rituális szerepek pedig csak rosszul játszhatók újra.

\section{Bibliográfia}

Bihary Gábor. 2016. „,Ez egy transzvesztita könyv. ” Horváth Imre Olivér nem szimpátia címü könyvének bemutatója. KULTer. http://kulter.hu/2016/12/ez-egytranszvesztita-konyv/

Butler, Judit. 2006. Problémás nem. Ford. Berán Eszter, Vándor Judit. Budapest: Balassi.

Csehy Zoltán. 2014. Szodoma és környéke. Homoszocialitás, barátságretorika és queer irányulások a magyar költészetben. Pozsony: Kalligram.

Csehy Zoltán. 2019. Ex libris. In Élet és Irodalom 63 (41. szám, 2019. 10. 11.), 19. 
Horkay Hörcher Ferenc. 2012. Hume és az ízlésesztétika brit paradigmája. Magyar Filozófiai Szemle 56, 1. 43-60.

Horváth Imre Olivér. 2016. nem szimpátia. Budapest: Fiatal Írók Szövetsége.

Jagose, Annamarie 2003. Ford. Sándor Bea. Bevezetés a queer elméletbe. Budapest: Új Mandátum.

Konkoly Dániel. 2017. Szövegek és nemek között. In Alföld 68 (2017/12), 103-107.

Lesi Zoltán. 2019. Magasugrás. Budapest: Prae Kiadó.

Mezei Gábor. 2019. Ex libris. In Élet és Irodalom 63 (47. szám, 2019. 11. 22.), 19.

Olty Péter. 2019. Heteró közegben. Budapest: Scolar.

Pilinszky János. 1992. Összegyüjtött versei. Budapest: Századvég Kiadó.

Reed, Christopher. 2011. Art and Homosexuality. A History of Ideas. Oxford: Oxford University Press. 


\title{
The Body of the Text as Playground and Battlefield
}

\section{Zoltán Csehy, Comenius University in Bratislava, Faculty of Arts, Department of} Hungarian Language and Literature

\begin{abstract}
The study deals with the new collections of poetry of three young Hungarian poets (Zoltán Lesi, Imre Olivér Horváth and Péter Olty) and examines their narrative strategies regarding to the poetical and rhetorical tension between the heteronormativity and queerness. The author maps the queering strategies of the tradition and, through this method, shows the development of self-fashioning as a performative act, intertextual interventions to the classics, and the fragmentation of self, gender and norms. Zoltán Lesi works off the relationship between the intersexuality and the power-strategies of sports (as a metaphor for political and ideological aggression), Imre Olivér Horváth creates a kind of new camp mythology, Péter Olty dissolves the heteronormativity using the classical mythological camouflage and the analogy of computer games.
\end{abstract}

Keywords: queer, contemporary Hungarian poetry, intersexuality, heteronormativity.

(Telo)tekst kao bojno polje i igralište

Zoltan Čehi, Univerzitet Komenskog u Bratislavi, Filozofski fakultet, Katedra za mađarski jezik i književnost

\section{Sažetak}

Studija se bazira na tri nove zbirke pesama mladih mađarskih pisaca (Zoltana Lešija, Imrea Olivera Horvata i Petera Oltija) fokusirajući se na strukturu odnosa poetičke i retoričke tenzije između heteronormativnog sistema očekivanja i kvir tematike. Autor mapira strategije kvirizacije tradicije, i uz pomoć ove metode prikazuje performativne akte oformljavanja sopstva, uplive intertekstualnosti u klasični, tradicionalni tekst i simptome fragmentalizacije sopstva, pola i norme. Zoltan Leši obrađuje veze između interseksualnosti i taktike moći u sportu (kao metaforu za političku i ideološku agresiju), Imre Oliver Horvat stvara novu kemp mitologiju, dok Peter Olti rastvara pravila heteronormativnosti koristeći se klasičnom mitološkom kamuflažom i kompjuterskim igricima.

Ključne reči: kvir, savremena mađarska poezija, interseksualnost, heteronormativnost. 